\title{
The effect of hormonal estrus induction on maternal effect and apoptosis-related genes expression in porcine cumulus-oocyte complexes
}

\author{
Marek Bogacki ${ }^{*}$, Marta Wasielak', Anna Kitewska ${ }^{1}$, Iwona Bogacka ${ }^{2}$ and Beenu Moza Jalali ${ }^{1}$
}

\begin{abstract}
Background: The effect of hormonal estrus induction on maternal effect (MATER - maternal antigen that embryo requires, ZAR-1 - zygote arrest 1, and BMP15 - bone morphogenetic protein 15) and apoptosis-related genes expression $(B C L-2$ and $B A X)$ in porcine cumulus-oocyte complexes (COCs) and selected follicular parameters was investigated in this study.

Methods: Gilts were divided into three groups: (I) with natural estrus; (II) stimulated with PMSG/hCG; and (III) with PMSG/hCG + PGF2alpha. Analysis of maternal effect and apoptosis-related transcripts expression in COCs, and progesterone synthesis pathway genes expression (P450scc and 3betaHSD) in granulosa cells was performed by qPCR. BMP15 protein expression in follicular fluid (FF) was analyzed by western blot. Oocyte nuclear maturation was assessed by aceto-orcein staining. Progesterone (P4) and estradiol (E2) concentrations in FF and serum were measured by ELISA. Data were analyzed with the one-way ANOVA and Bonferroni post-test or Kruskal-Wallis test and Dunns post-test.
\end{abstract}

Results: The highest expression of MATER, ZAR-1, and BMP15 genes was found in COCs recovered from gilts treated with PMSG/hCG when compared to PMSG/hCG + PGF2alpha-stimulated or non-stimulated gilts. Hormonal treatment did not affect the BMP15 protein expression in FF, but increased the expression of genes participating in P4 synthesis in granulosa cells. The higher percentage of immature oocytes was found in PMSG/hCG-treated when compared to the non-stimulated gilts. The expression of $B C L-2$ and $B A X m R N A$, and $B C L-2 / B A X m R N A$ ratio was significantly higher in COCs derived from PMSG/hCG-treated when compared to PMSG/hCG + PGF2alpha-treated or non-stimulated subjects. The level of P4 in serum was similar in animals from all experimental groups, while its concentration in FF was greater in gilts subjected to PMSG/hCG treatment than in PMSG/hCG + PGF2alpha-stimulated and non-stimulated gilts. The concentration of E2 did not differ in the serum or FF between the control group and the hormonally stimulated groups.

Conclusions: Hormonal induction of estrus affected maternal effect gene transcripts levels in COCs and and oocyte nuclear maturation. The inclusion of PGF2alpha into the stimulation protocol enabled maintaining of physiological concentration of P4 in FF. Additionally, both hormonal treatments seem to be beneficial for apoptosis prevention through increasing $B C L-2 / B A X$ transcript ratio.

Keywords: Maternal effect genes, Pig, Estrus induction, Gonadotropins

\footnotetext{
* Correspondence: m.bogacki@pan.olsztyn.pl

${ }^{1}$ Institute of Animal Reproduction and Food Research of Polish Academy of

Sciences, Tuwima 10, Olsztyn 10-748, Poland

Full list of author information is available at the end of the article
} 


\section{Background}

Hormonal induction of the estrus is commonly used in commercial swine breeding to improve production efficiency and facilitate animal management. It also serves as a fundamental technique in the preparation of recipients and donors for embryo transfer procedures, as well as in the recovery of a large number of embryos used later for both biotechnological purposes and in basic studies. However, the administration of gonadotropins may be to some extent detrimental to the reproductive performance of the treated animals. Estrus induction in gilts has an impact on follicular development, as reflected by the changes in follicle diameter and follicular fluid volume compared to naturally cyclic pigs [1]. In our earlier studies, a higher number of degenerated porcine embryos and a lower number of blastocysts hatched in vitro were found after hormonal induction of the estrus [2]. Moreover, studies have shown that hormonal treatment affects the expression of genes crucial for pre-implantation events in the uterus and conceptus during early pregnancy [3] and increases embryonic losses in pigs [4].

One of the predominant factors affecting proper embryo development and successful pregnancy is oocyte quality. During cytoplasmic maturation, the oocyte increases its size and volume, and a large number of mRNAs and proteins are accumulated at that time. These molecules, identified as maternal effect genes products, regulate events crucial for oocyte meiosis completion (nuclear maturation), organization of two pronuclei, and first embryo cleavages [5,6]. An expression of ZAR-1 (zygote arrest 1), one of the maternal effect genes, was found in porcine oocytes and early embryos recovered in vivo; but it decreased significantly at the morula and blastocyst stages [7]. These indicate that ZAR-1 has a significant function in oocyte development and during the first embryonic cleavages. $M A T E R$ (maternal antigen that an embryo requires or NALP5), which also belongs to the maternal effect genes, was found to play a role in activating embryonic genome and maintaining chromosome stability and euploidy in mice $[8,9]$. Interestingly, recent data show that, during folliculogenesis, MATER is expressed and exerts its biological role also in the surrounding cumulus cells [10], which confirms the importance of the intimate relationship between oocyte and cumulus cells for the production of a fully competent gamete.

An example of another kind of maternal effect gene is bone morphogenetic protein 15 (BMP15). BMP15 belongs to the TGF- $\beta$ superfamily and is known as a granulosa cell mitosis and proliferation inducer $[11,12]$. The production of adequate amounts of BMP15 protein by the oocyte is necessary to promote cumulus cells expansion [13]. The expression of BMP15 mRNA was also found in cumulus cells and it decreased along with the oocyte maturation and cumulus expansion in vitro [14].
Knockout of BMP15 in female mice decreased fertility and diminished embryonic development [15]. There are studies demonstrating that the BMP15 level in follicular fluid (FF) appears to be a potential marker in predicting oocyte quality and subsequent embryo development $[15,16]$.

Although there are some reports on maternal effect genes expression and their cellular localization during porcine oocyte maturation and embryo development in vitro $[5,7,17-19]$, there is no evidence showing the effect of hormonal treatment on their expression in this species. The most commonly applied protocols of estrus induction include the use of a combination of PMSG to stimulate follicular development and hCG to induce ovulation. However, it was suggested by Sommer et al. [20] that including PGF2 $\alpha$ into the PMSG/hCG protocol was very effective for collecting pronuclear stage embryos. Taking the following into consideration: (1) our previous results that estrus induction decreased embryo quality in pigs, (2) the information that genetic material within the oocyte plays an important role in directing the numerous events required for successful folliculogenesis and early embryo development, and (3) the fact that an luteinizing hormone (LH) surge causes the change from estradiol $\left(E_{2}\right)$ to domination of progesterone $\left(\mathrm{P}_{4}\right)$, we investigated the effect of the two mentioned regimens of exogenous gonadotropins treatment on selected maternal effect gene expression (MATER, ZAR-1 and $B M P 15)$ in COCs, steroid hormones concentration in $\mathrm{FF}$, and $\mathrm{P}_{4}$ synthesis pathway gene expression (P450scc and $3 \beta H S D$ ) in granulosa cells. Additionally, we examined apoptosis-related gene expression (antiapoptotic $B C L-2$ and proapoptotic $B A X)$ and $B C L-2 / B A X$ mRNA ratios in COCs in response to hormonal induction of the estrus.

\section{Methods \\ Animals}

The experiment was performed on gilts from one commercial herd, each 6.5 months old and on average weighing $115 \mathrm{~kg}$. Gilts were divided into three groups (five to eight animals per group). Briefly, from the group of animals, the gilts entering into their natural estrus cycle were assigned to the natural cyclic group (group I), and the remaining gilts were assigned to groups II and III and treated hormonally to induce first and second estrus. Animals from group I $(n=8)$, exhibiting first and second estrus naturally, were not hormonally stimulated. Gilts were considered to be in estrus when they responded to boar exposure. The animals assigned to groups II and III were treated with PMSG [Folligon'; Intervet, Netherlands; $750 \mathrm{IU} \mathrm{im}]$, followed by hCG [Chorulon; Intervet, Netherlands; $500 \mathrm{IU}$ im] 72 h later. After seventeen days, the second estrus in animals from group II $(n=5)$ was induced by an identical treatment of PMSG and hCG. Animals from group III $(n=7)$, 
between days twelve and sixteen of the second estrus, were treated with PGF2 $\alpha$ [Dinolitic ${ }^{\circledR}$; Pfizer, Poland; $10 \mathrm{mg} \mathrm{im}$ ], followed $24 \mathrm{~h}$ later with $10 \mathrm{mg}$ of PGF2 $\alpha$ simultaneously with 750 IU of PMSG, then followed $72 \mathrm{~h}$ later with $500 \mathrm{IU}$ of hCG. This procedure was a modification of the method described previously by Sommer et al. [20]. The gilts were slaughtered about $36 \mathrm{~h}$ after hCG administration. Blood samples were collected, incubated overnight at $4^{\circ} \mathrm{C}$ and then centrifuged $3000 \mathrm{X} \mathrm{g}$ for $20 \mathrm{~min}$ at $4^{\circ} \mathrm{C}$. Serum was harvested and frozen at $-20^{\circ} \mathrm{C}$ for $\mathrm{P}_{4}$ and $\mathrm{E}_{2}$ analysis.

All procedures were conducted in accordance with the national guidelines for agricultural animal care and were approved by the Local Animal Ethics Committee, University of Warmia and Mazury in Olsztyn, Poland.

\section{Recovery of COCs and granulosa cells}

The number of preovulatory follicles on each ovary was counted. Cumulus oocyte complexes (COCs) were recovered by cutting the follicles with a scalpel on a Petri dish. They were washed twice in Medium 199 (Sigma, St. Louis, MO, USA) supplemented with $0.68 \mathrm{mM}$ L-glutamine (Sigma), $20 \mathrm{mM}$ Hepes (Sigma), $100 \mathrm{U} / \mathrm{ml}$ penicillin (Sigma), $0.1 \mathrm{mg} / \mathrm{ml}$ streptomycin (Sigma) and 10\% fetal bovine serum (FBS; Invitrogen, Carlsbad, CA, USA). After washing twice in phosphate-buffered saline, the COCs from one animal were pooled in groups of ten to fifteen per tube, snap frozen in liquid nitrogen, and kept at $-80^{\circ} \mathrm{C}$ until further RNA isolation. At the same time, FF was collected (per animal - FF from all preovulatory follicles from both ovaries was pooled), centrifuged to remove cell debris, and frozen at $-20^{\circ} \mathrm{C}$ for $\mathrm{P}_{4}$ and $E_{2}$ analysis. The granulosa cells were gently scraped from the inner follicle wall and transferred to a $1.5 \mathrm{ml}$ microcentrifuge tube in phosphate-buffered saline and centrifuged at $90 \mathrm{X} \mathrm{g}$ for $10 \mathrm{~min}$ at room temperature. After centrifugation, the supernatant was removed and the cells were snap frozen in liquid nitrogen and stored at $-80^{\circ} \mathrm{C}$ for further RNA isolation.

\section{Evaluation of nuclear maturation}

For evaluation of oocyte nuclear maturation, additional animals prepared as described previously were used [natural estrus (group I) $\mathrm{n}=4$; PMSG/hCG (group II) $\mathrm{n}=3$; PMSG/hCG + PGF2 $\alpha$ (group III) $\mathrm{n}=3$ ]. After the recovery of COCs, cumulus cells were removed completely by vortexing in $0.1 \%(\mathrm{w} / \mathrm{v})$ hyaluronidase (Sigma). Denuded oocytes were placed on a glass slide under a cover slip (supported with Vaseline corners) and fixed for up to $72 \mathrm{~h}$ in an acetic acid/ethanol fixative (1:3, v:v). Nuclear structures were then visualized by staining with acetoorcein (1\% orcein in $45 \%$ acetic acid). Oocytes were evaluated under a phase-contrast microscope for the stage of nuclear maturation. Based on the stage of nuclear maturation, oocytes were divided into two groups: immature oocytes (GV) and oocytes that resumed meiosis (prometaphase I - metaphase II).

\section{$\mathrm{P}_{4}$ and $\mathrm{E}_{2}$ measurement}

Concentrations of $\mathrm{P}_{4}$ and $\mathrm{E}_{2}$ in FF and serum were determined using commercial ELISA kits (Enzo Life Sciences, New York, NY, USA) according to the supplier's instructions. The standard curves for $\mathrm{P}_{4}$ and $\mathrm{E}_{2}$ ranged from 15.6 to $500 \mathrm{pg} / \mathrm{ml}$ and from 15.6 to $1000 \mathrm{pg} / \mathrm{ml}$, respectively. The concentrations of $\mathrm{P}_{4}$ and $\mathrm{E}_{2}$ in FF and serum were measured in duplicates for each sample and the final concentration was expressed as an average. Assay sensitivity was $8.57 \mathrm{pg} / \mathrm{ml}$ for $\mathrm{P}_{4}$ and $14.00 \mathrm{pg} / \mathrm{ml}$ for $E_{2}$. The intra-assay coefficients of variation were $5.9 \%$ for $\mathrm{P}_{4}$ and $4.9 \%$ for $\mathrm{E}_{2}$.

\section{RNA isolation and qPCR}

Total RNA from COCs and granulosa cells was isolated using Qiagen RNeasy ${ }^{\circ}$ Plus Micro Kit (Qiagen, Valencia, CA, USA) and checked for quantity and quality with NanoDrop ${ }^{\circledR}$ (ND-1000; Thermo Scientific, Waltham, MA, USA). DNase treatment with gDNA eliminator columns (Qiagen) was included in the RNA isolation protocol. The RNA obtained was reversely transcribed with the use of a transcriptor high fidelity cDNA synthesis kit (Roche, Basel, Switzerland). For reverse transcription, $15 \mathrm{ng}$ of total RNA from COCs and $1 \mu \mathrm{g}$ of RNA from granulosa cells were used. The reaction was performed in a total volume of $20 \mu \mathrm{l}$, including RNA, water, $60 \mu \mathrm{M}$ of random hexamer primers, reaction buffer, $5 \mathrm{mM}$ DTT, $20 \mathrm{U}$ Protector RNase inhibitor, $1 \mathrm{mM}$ deoxynucleotide mix, and $10 \mathrm{U}$ of reverse transcriptase. At first, the template-primer mixture was denatured by heating the tube for $10 \mathrm{~min}$ at $65^{\circ} \mathrm{C}$ in a thermo cycler (SensoQuest $\mathrm{GmbH}$, Göttingen, Germany). Then, after adding the remaining components of the mixture, the following thermal profile of the reaction was applied: $30 \mathrm{~min}$ at $45^{\circ} \mathrm{C}$ followed by inactivation of reverse transcriptase at $85^{\circ} \mathrm{C}$ for $5 \mathrm{~min}$, with subsequent cooling to $4^{\circ} \mathrm{C}$. cDNA was kept at $-20^{\circ} \mathrm{C}$ for further qPCR analysis.

Power SYBR Green PCR Master Mix (Life Technologies, Carlsbad, CA, USA) was used for qPCR analysis. The primers used for $\mathrm{qPCR}$, products sizes, and GenBank accession numbers and/or references are included in Table 1. The qPCR mix consisted of $2 \mu \mathrm{l}$ of RT product, $1 \mu \mathrm{l}$ of forward and reverse primer $(0.4 \mu \mathrm{M}), 8.5 \mu \mathrm{l}$ of nuclease-free water, and $12.5 \mu \mathrm{l}$ of SYBR Green. The reaction was performed manually in duplicates for each sample, at a final volume of $25 \mu \mathrm{l}$ in 96-well plates using ABI 7300 (Life Technologies). Each run included a nontemplate control (NTC). A standard curve was generated by amplifying serial dilutions of a known quantity of cDNA. The amplification efficiency for each gene was 
Table 1 Primers used for qPCR

\begin{tabular}{|c|c|c|c|}
\hline Gene & Primer sequence & Amplicon size (base pairs) & GenBank accession no./reference \\
\hline \multirow[t]{2}{*}{ MATER } & F: GATTAACGCCCAGCTCTTGT & 154 & AM748274.1 \\
\hline & R: AGCTTCTGCAGAGTGCAGTG & & \\
\hline \multirow[t]{2}{*}{ ZAR-1 } & F: TGGTGTGTCCAGGGCACTAA & 213 & NM_001129956 \\
\hline & R: GTCACAGGAGAGGCGTTTGC & & \\
\hline \multirow[t]{2}{*}{ BMP15 } & F: AGCTTCCACCAACTGGGTTGG & 285 & Li et al. [17] \\
\hline & R: TCATCTGCATGTACAGGGCTG & & \\
\hline \multirow[t]{2}{*}{$B A X$} & F: AAGCGCATTGGAGATGAACT & 159 & Wasielak et al. [22] \\
\hline & R: AAAGTAGAAAAGCGCGACCA & & \\
\hline \multirow[t]{2}{*}{$B C L-2$} & F: GAAACCCCTAGTGCCATCAA & 196 & Ju et al. [23] \\
\hline & R: GGGACGTCAGGTCACTGAAT & & \\
\hline \multirow[t]{2}{*}{ P450scc } & F: TITACAGGGAGAAGCTCGGCAAC & 251 & Walzel et al. [24] \\
\hline & R: TTACCTCCGTGTTCAGGACCAAC & & \\
\hline \multirow[t]{2}{*}{$3 \beta H S D$} & F: GGGTTTCTGGGTCAGAGGATC & 236 & Walzel et al. [24] \\
\hline & R: CGTTGACCACGTCGATGATAGAG & & \\
\hline \multirow[t]{2}{*}{ GAPDH } & F: TCGGAGTGAACGGATTTG & 219 & Kuijk et al. [21] \\
\hline & R: CCTGGAAGATGGTGATGG & & \\
\hline
\end{tabular}

found to be between 90 and 100\% for all the investigated genes. The thermal profile for amplification of the investigated genes was as follows: preincubation at $95^{\circ} \mathrm{C}$ for $15 \mathrm{~min}$, followed by 45 cycles of denaturation at $95^{\circ} \mathrm{C}$ for $15 \mathrm{~s}$, annealing at either $52^{\circ} \mathrm{C}$ (for glyceraldehyde-3phosphate dehydrogenase; GAPDH), $55^{\circ} \mathrm{C}$ (for $B M P 15$, $M A T E R, Z A R-1), 57^{\circ} \mathrm{C}$ (for $B C L-2$ ), or $60^{\circ} \mathrm{C}$ (for $B A X$, $P 450 \mathrm{scc}, 3 \beta H S D)$ for $30 \mathrm{~s}$, and elongation at $72^{\circ} \mathrm{C}$ for $30 \mathrm{~s}$. After the end of the last cycle, the melting curve was generated. Product purity was confirmed by electrophoresis and its specificity was confirmed by sequencing (Genomed, Warsaw, Poland). The obtained sequences were compared with the expected sequences of the investigated genes using BLAST (bl2seq). The final quantification was reported as a relative expression (average value from duplicates) after normalization to reference gene $(G A P D H)$ expression in the same samples. GAPDH was selected as a good reference gene candidate for pig oocytes and embryos for the reasons suggested by Kuijk et al. [21]. There was no statistically significant impact of the treatments on GAPDH transcript level in our study, confirming its usefulness as a good endogenous control.

\section{Western blot}

A western blot of the BMP15 protein was carried out according to the method described previously by $\mathrm{Wu}$ et al. [15] and Paradis et al. [25]. Protein concentration in FF was determined according to the Bradford [26]. Briefly, $0.75 \mu \mathrm{g}$ of protein in an SDS-gel loading buffer (50 mM TRIS-HCl, 4\% SDS, 20\% glycerol, and 2\% $\beta$-mercaptoethanol) was heated to $95^{\circ} \mathrm{C}$ for $4 \mathrm{~min}$, electrophoretically separated on a $12 \%$ polyacrylamideSDS gel for $1.5 \mathrm{~h}$ at a constant current (200 mA), and then transferred overnight onto a nitrocellulose membrane. After the transfer, the membranes were stained with Ponceau $\mathrm{S}$ for total protein loading. They were then blocked in a solution of $5 \%(\mathrm{w} / \mathrm{v})$ non-fat dry milk for $1.5 \mathrm{~h}$. The expression of BMP15 was determined with the use of a primary polyclonal rabbit anti-human BMP15 antibody (Santa Cruz Biotechnology, Inc., Santa Cruz, CA, USA), diluted 1:400 in blocking solution. The secondary antibody used was goat anti-rabbit IgG conjugated with alkaline phosphatase (Sigma), diluted 1:20,000 in blocking solution containing pig protein. The molecular weight of the bands was determined by reference to a standard molecular weight marker. Three immunoreactive bands were found, representing BMP15 promature protein $(65 \mathrm{kDa})$, cleaved proregion $(50 \mathrm{kDa})$, and mature protein $(25 \mathrm{kDa})$. The intensity of the bands was quantified by measuring optical density using Kodak $^{\bullet}$ ID image analysis software (Eastman Kodak, Rochester, NY, USA). A control sample (a mix of all samples analyzed) was loaded on each gel to correct for interblot variability [15,25]. Densitometric values for individual FF samples were normalized to a stable protein band quantified after Ponceau S staining. All samples were electrophoresed and analyzed in duplicate, and values were averaged before statistical analysis [15,25].

\section{Statistical analysis}

The statistical analysis was carried out with the use of GraphPad PRISM v. 5.0 software (GraphPad Software, Inc., San Diego, CA, USA). Normality (bell shaped 
distribution) and homoscedasticity (variances) of the data were tested before analysis. For the data fitting the assumptions of parametric tests, i.e., following normal distribution and having similar variances, a one-way ANOVA and Bonferroni post-test was applied. For data that did not meet the assumptions of parametric tests (not following normal distribution or having different variances), the non-parametric Kruskal-Wallis test and Dunn post-test were done.

With regard to the pigs' reproductive parameters (such as the number of follicles, oocyte nuclear maturation, hormone concentration in FF and serum), the data did not show normal distribution and/or similar variances even after logarithmic or arcsine transformation (in case of the data concerning oocyte nuclear maturation); therefore we analyzed them with the non-parametric Kruskal-Wallis test and Dunn post-test. Because of different variances, the data of $Z A R-1, B M P 15, B A X$, and $B C L-2 / B A X$ mRNA expression were logarithmically transformed and analysis was done on the transformed data. These data were analyzed with the use of a one-way ANOVA and Bonferroni post-test. MATER, BCL-2, P450scc, 3BHSD mRNA and BMP15 protein expression data, which did not show normal distribution, were analyzed with the use of the non-parametric Kruskal-Wallis test and Dunn post-test. $\mathrm{P}$ values less than 0.05 were considered significant. Results are presented as ls mean \pm S.E.M.

\section{Results}

The effect of hormonal treatments on follicle numbers, oocyte nuclear maturation, and steroids concentrations $\left(P_{4}\right.$ and $\left.E_{2}\right)$ in $F F$ and blood serum

The number of preovulatory follicles per gilt did not differ between the experimental groups of gilts (Table 2). A higher percentage of immature oocytes was found in PMSG/hCG-treated animals (group II) when compared to the naturally cyclic animals (group I) $(\mathrm{p}<0.05$; Figure 1). The percentage of oocyte nuclear maturation did not differ between PMSG/hCG-treated animals (group II) and PMSG/hCG + PGF2 $\alpha$-treated animals (group III) ( $\mathrm{p}>0.05)$.

$\mathrm{P}_{4}$ concentration in blood serum did not differ between the experimental groups of animals ( $p>0.05$; Table 2). However, its concentration in FF was significantly higher in gilts stimulated with PMSG/hCG (group II) compared to those stimulated with PMSG/hCG + PGF $2 \alpha$ (group III) or in the naturally cyclic animals (group I) ( $<0.01$; Table 2). There was no difference in $\mathrm{P}_{4}$ concentration in FF between naturally cyclic (group I) and PMSG/hCG + PGF $2 \alpha$-treated animals (group III) $(\mathrm{p}>0.05)$.

There was no difference in $\mathrm{E}_{2}$ concentration in blood serum between the PMSG/hCG-treated gilts (group II), PMSG/hCG + PGF2 $\alpha$-treated gilts (group III), and naturally cyclic gilts (group I) ( $>>0.05$; Table 2 ). The same observation was made regarding $\mathrm{E}_{2}$ concentration in $\mathrm{FF}$ (Table 2).

The effect of hormonal treatments on the expression of maternal effect (MATER, ZAR-1, BMP15) and apoptosisrelated ( $B C L-2$ and $B A X)$ genes, $B C L-2 / B A X$ mRNA ratio in COCs and BMP15 protein in FF

The highest expression of MATER, ZAR-1, BMP15 genes was found in the COCs recovered from gilts treated with PMSG/hCG (group II), when compared to the PMSG/ hCG + PGF2 $\alpha$-stimulated (group III) and naturally cyclic gilts (group I) $(\mathrm{p}<0.01$; Figure 2). Additionally, maternal effect gene expression was higher in the COCs of PMSG/hCG + PGF2 $\alpha$-treated gilts (group III) than in the naturally cyclic gilts (group I) $(\mathrm{p}<0.05)$.

Hormonal treatment did not affect BMP15 protein level in FF. The densitometric analysis of all three detected bands of BMP15 (analyzed separately) indicated that there were no differences in BMP15 forms expression in FF between experimental groups (marked at $\mathrm{p}<$ 0.05; Figure 3).

The expression of apoptosis-related gene $B C L-2$ was significantly higher $(\mathrm{p}<0.05)$ in COCs derived from gilts

Table 2 The effect of hormonal treatments on follicle numbers and steroids concentrations in FF and serum

\begin{tabular}{|c|c|c|c|c|}
\hline & \multicolumn{3}{|c|}{ Treatment } & \multirow[t]{2}{*}{$p$} \\
\hline & Natural estrus & PMSG/hCG & PMSG/hCG + PGF2a & \\
\hline Follicles per gilt & $20.13 \pm 2.33$ & $14.00 \pm 2.14$ & $15.43 \pm 1.87$ & ns \\
\hline \multicolumn{5}{|l|}{ Steroids in FF } \\
\hline \multirow[t]{2}{*}{$P_{4}(n g / m l)$} & $50.24 \pm 7.47^{\mathrm{a}}$ & $223.2 \pm 31.38^{\mathrm{b}}$ & $80.03 \pm 11.03^{a}$ & $a$ vs. b \\
\hline & & & & $p<0.01$ \\
\hline$E_{2}(n g / m l)$ & $13.18 \pm 4.35$ & $6.176 \pm 2.25$ & $5.50 \pm 1.12$ & ns \\
\hline \multicolumn{5}{|c|}{ Steroids in blood serum } \\
\hline$P_{4}(n g / m l)$ & $1.86 \pm 0.21$ & $1.25 \pm 0.16$ & $1.28 \pm 0.16$ & ns \\
\hline$E_{2}(p g / m l)$ & $55.24 \pm 9.18$ & $47.45 \pm 5.41$ & $71.95 \pm 21.08$ & ns \\
\hline
\end{tabular}

Follicles number and $\mathrm{P}_{4}$ and $\mathrm{E}_{2}$ concentration in follicular fluid and blood serum recovered from non-stimulated gilts with natural estrus (group $\mathrm{l} ; \mathrm{n}=8$ ), stimulated with PMSG/hCG (group II; $n=5$ ) or with PMSG/hCG + PGF2a (group III; $n=7$ ). Values are expressed as Is mean \pm S.E.M. 


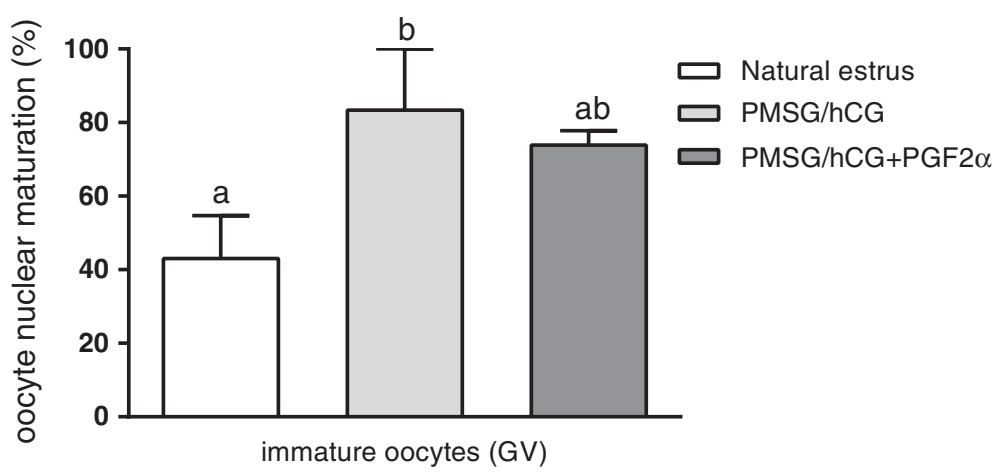

Figure 1 The nuclear maturation of oocytes. The comparison of nuclear maturation of oocytes derived from non-stimulated gilts with natural estrus (group I; $n=4$ ), stimulated with PMSG/hCG (group II, $n=3$ ) or with PMSG/hCG + PGF2a (group III, $n=3$ ). Values are expressed as percentages of immature oocytes (germinal vesicle; GV). Significant differences between groups were marked with $p<0.05$.

treated with PMSG/hCG (group II; Figure 4), compared to PMSG/hCG + PGF2 $\alpha$-treated gilts (group III) or the naturally cyclic animals $(\mathrm{p}<0.05)$; Figure 4 . Moreover, its expression was enhanced in COCs recovered from PMSG/hCG-treated gilts (group II) compared to PMSG/ hCG + PGF2 $\alpha$-treated gilts (group III) $(\mathrm{p}<0.05)$.

In the case of $B A X$ mRNA expression, it was significantly higher in COCs of PMSG/hCG-stimulated gilts (group II) compared to PMSG/hCG + PGF2 $\alpha$-stimulated gilts (group III) and the naturally cyclic gilts (group I) ( $<<0.05$; Figure 4). The expression of $B A X$ mRNA was comparable in the PMSG/hCG + PGF2 $\alpha$-treated gilts (group III) and in the naturally cyclic gilts (group I) (p > 0.05).

The ratio of $B C L 2 / B A X$ mRNA was higher in COCs of gilts treated with PMSG/hCG (group II) than in the other two groups $(\mathrm{p}<0.01$; Figure 4$)$. Additionally, a significantly higher $B C L-2 / B A X$ mRNA ratio was found in PMSG/hCG + PGF2 $\alpha$-treated (group III) animals than in animals attaining estrus naturally (group I) $(\mathrm{p}<0.05)$.

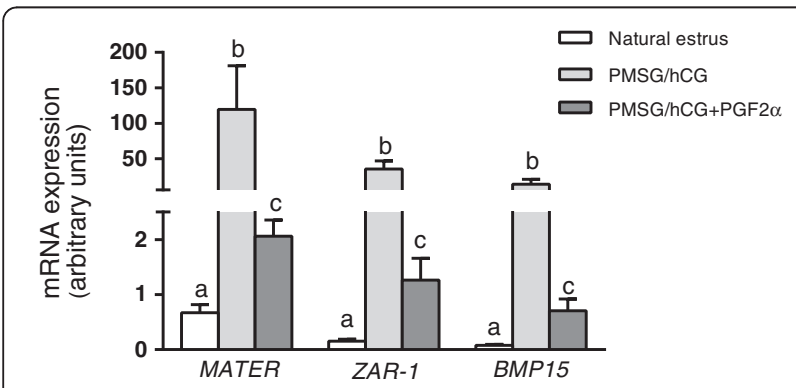

Figure $\mathbf{2}$ The expression of maternal effect genes in porcine COCs. The comparison of the expression of maternal effect genes (MATER, ZAR-1 and BMP15) in COCs derived from non-stimulated gilts with natural estrus (group $1 ; n=8$ ), stimulated with PMSG/hCG (group II; $\mathrm{n}=5$ ) or with PMSG/hCG + PGF2a (group III; $\mathrm{n}=7$ ). Values from qPCR were normalized to GAPDH expression. Different superscripts depict significant statistical differences at $p<0.05$. Data are expressed in arbitrary units as the Is mean \pm S.E.M.
The effect of hormonal treatments on the expression of $\mathrm{P}_{4}$ synthesis pathway genes (P450scc and $3 \beta H S D$ ) in granulosa cells

Regarding expression of P450scc mRNA, it was significantly increased in granulosa cells from females subjected to hormonal treatment with PMSG/hCG + PGF2 $\alpha$ (group III) in comparison to granulosa cells recovered from naturally cyclic animals (group I) and PMSG/hCGtreated animals (group II) ( $\mathrm{p}<0.05$; Figure 5). Additionally, we did not find any difference in P450scc mRNA expression in granulosa cells obtained from gilts stimulated with PMSG/hCG (group II) and the naturally cyclic gilts (group I) ( $>$ > 0.05; Figure 5).

The expression of $3 \beta H S D$ mRNA was significantly increased in granulosa cells recovered from gilts stimulated with PMSG/hCG + PGF2 $\alpha$ (group III), compared to its expression in granulosa cells obtained from naturally cyclic gilts (group I) ( $<<0.001$; Figure 5). Moreover, its expression was also increased in granulosa cells of PMSG/hCG-treated animals (group II) compared to naturally cyclic pigs (group I) $(\mathrm{p}<0.05)$.

\section{Discussion}

The paper presents the results on the effect of hormonal estrus induction on COCs quality and selected follicular parameters in the pig.

We found that hormonal stimulation of gilts with PMSG/hCG or PMSG/hCG + PGF $2 \alpha$ did not affect the follicle number when compared with naturally cyclic animals. It had been previously reported that in pregnant females the number of corpora lutea and the fertilization rate were comparable between non-stimulated and PMSG/hCG-treated pigs [3]. On the other hand, Kiewisz et al. [27] showed that treatment with PMSG/hCG + PGF $2 \alpha$ generated a higher number of corpora lutea and conceptuses when compared to animals attaining estrus naturally. This observation was not confirmed in the 


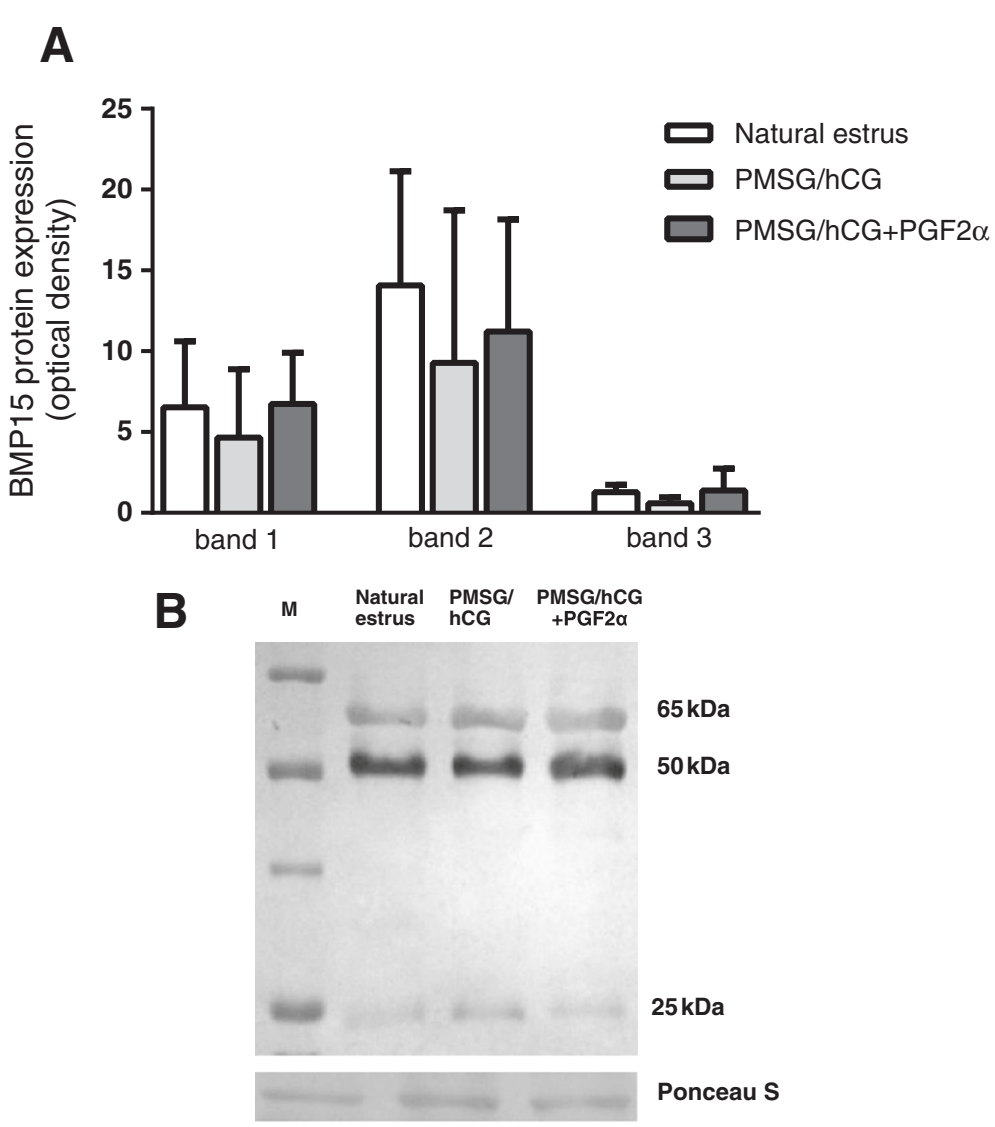

Figure 3 The expression of BMP15 protein in FF. The comparison of expression of BMP15 protein (A) in follicular fluid derived from nonstimulated gilts with natural estrus (group I; $n=8$ ), stimulated with PMSG/hCG (group II; $n=5$ ) or with PMSG/hCG + PGF2a (group III; $n=7$ ). Representative bands of western blots are presented (B). The bands represent three forms of BMP15 found in FF: premature protein (band 1, $\sim 65 \mathrm{kDa}$ ), cleaved proregion (band 2, 50 kDa) and mature protein (band 3, 25 kDa). Data are expressed in arbitrary optical density units as the Is mean \pm S.E.M. Different superscripts depict significant statistical differences at $p<0.05$.

present study with regard to follicular growth; however, the discrepancy may result from differences in animal treatment. In the cited study of Kiewisz et al. [27], gilts were assigned for hormonal stimulation in their third estrus, while in our study animals with two consecutively stimulated estruses were used.
In the present study, we observed a markedly higher expression of all the investigated maternal effect gene transcripts (MATER, ZAR-1, BMP15) in COCs recovered from animals treated hormonally with PMSG/hCG or PMSG/hCG + PGF2 $\alpha$, when compared with those observed in naturally cyclic females. This high expression

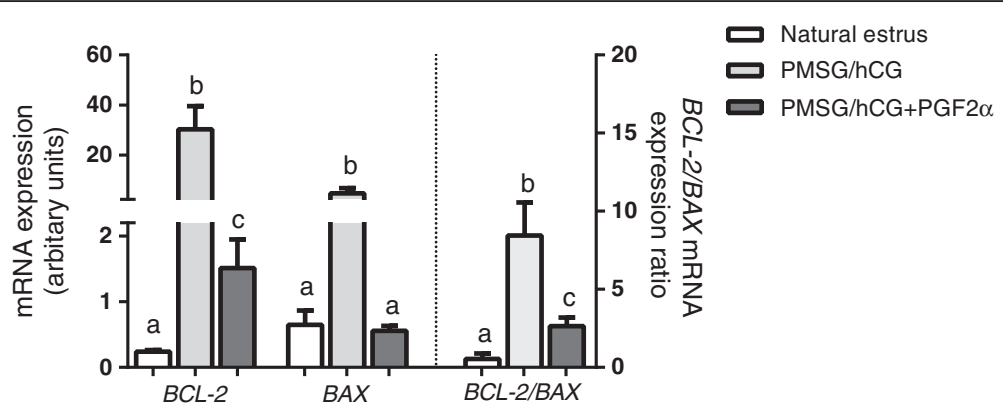

Figure 4 The expression of apoptosis-related genes in porcine COCs. The comparison of the expression of apoptosis-related genes $B C L-2$, $B A X$ and $B C L-2 / B A X$ mRNA ratio in COCs derived from non-stimulated gilts with natural estrus (group $\mathrm{l} ; \mathrm{n}=8$ ), stimulated with PMSG/hCG (group $\| ; n=5$ ) or with PMSG/hCG + PGF2a (group III; $n=7$ ). Values from qPCR were normalized to GAPDH gene expression. Data are expressed in arbitrary units as the Is mean \pm S.E.M. Different superscripts depict significant statistical differences at $p<0.05$. 




Figure 5 The expression of $\mathrm{P}_{\mathbf{4}}$ synthesis pathway genes in porcine granulosa cells. The comparison of the expression of $\mathrm{P}_{4}$ synthesis pathway genes (3BHSD and P450sCC) in granulosa cells derived from non-stimulated gilts with natural estrus (group $; ; n=8$ ), stimulated with PMSG/hCG (group Il; $n=5$ ) or with PMSG/hCG + PGF2a (group III; $n=7$ ). Values from qPCR were normalized to GAPDH expression. Different superscripts depict significant statistical differences at $p<0.05$. Data are expressed in arbitrary units as the Is mean \pm S.E.M.

of maternal effect genes, particularly in COCs obtained from PMSG/hCG-stimulated pigs, seems to be associated with a higher number of immature oocytes that did not resume meiosis. It is well known that the intense synthesis of maternal transcripts precedes the onset of transcriptional silencing during the GV stage. The maternal transcripts undergo post-transcriptional regulation through shortening of the polyA tail, which enables their storage and protection from the translation machinery. After meiosis resumption, when the proteins are required, the transcripts are polyadenylated and used for translation, then rapidly degraded $[18,28]$. The high levels of the investigated maternal effect gene transcripts found in our study in COCs from hormonally treated animals, and the lower percentage of oocytes that resumed meiosis, may result from the fact that cellular mechanisms controlling transcription and/or translation in female gametes can be modified in these gilts in response to exogenous gonadotropins. Similarly, in studies on the development of porcine embryos, it was shown that disturbation in maternal mRNA degradation may be responsible for delayed cleavage of porcine embryos in vitro [29]. Together, these findings suggest that mechanisms of maternal transcript utilization are potential determinants of oocyte/embryo quality and developmental potential, and may be affected by factors such as hormonal stimulation and in vitro culture conditions.

The BMP15 protein level in FF is considered as potential marker of oocyte quality. The main role played by BMP15 protein in preovulatory follicles is to stimulate cumulus cell expansion $[13,14]$. The present study has shown that hormonal treatment of gilts markedly increased BMP15 transcript level in COCs but it did not affect BMP15 protein level in FF. Similar results were obtained by Paradis et al. [25] who also did not find correlation between BMP15 mRNA expression in oocytes and protein in FF during different phases of follicle development, suggesting that not necessarily protein by itself but rather its receptor can be influenced by gonadotropins in the pig.
In our experiment, the serum concentration of $\mathrm{P}_{4}$ did not differ between the experimental groups but was higher in the FF of PMSG/hCG compared to PMSG/ hCG + PGF2 $\alpha$-stimulated and non-stimulated females. Similarly, in the studies of Wiesak et al. [1] the concentration of $\mathrm{P}_{4}$ in $\mathrm{FF}$, recovered from follicles of nonstimulated gilts, was lower than in follicles obtained from gonadotropin-treated (PMSG/hCG) gilts at all stages of follicle development. The high concentration of $\mathrm{P}_{4}$ in FF obtained from PMSG/hCG-treated animals was associated with increased percentage of oocytes at the GV stage and increased levels of maternal effect gene transcripts in COCs. Shimada and Terada [30] found that $\mathrm{P}_{4}$ induces germinal vesicle breakdown (GVBD) in porcine oocytes, probably through the disruption of gap junction communication. Dynamic changes in the expression of $\mathrm{P}_{4}$ receptor proteins, following in vitro maturation in response to supplementation with $\mathrm{LH}$, follicle-stimulating hormone (FSH), or $\mathrm{P}_{4}$, also indicated the role of $\mathrm{P}_{4}$ in bovine oocyte maturation [31]. In the current in vivo study, the increased concentration of $\mathrm{P}_{4}$ in FF of PMSG/hCG-treated animals does not seem to support meiosis resumption in the oocytes. On the other hand, it was found that the addition of various concentrations of $\mathrm{P}_{4}$ to the maturation medium had negative effects on the percentage of oocytes completing nuclear or cytoplasmic maturation in porcine [32] and bovine oocytes [33].

Our results also indicate that the inclusion of PGF $\alpha \alpha$ into the synchronization protocol decreases the $\mathrm{P}_{4}$ concentration in follicles to the levels observed in the follicles of naturally cyclic gilts. A similar effect was observed in in vitro studies, where PGF2 $\alpha$ exerted a concentration-dependent inhibitory influence on gonadotropin-stimulated $\mathrm{P}_{4}$ production [34]. It can be suggested that including PGF2 $\alpha$ into an estrus stimulation protocol in the pig can be beneficial for obtaining more physiological concentration of $\mathrm{P}_{4}$ in $\mathrm{FF}$ and enhancing the natural hormonal environment for oocyte development. Maintaining the appropriate $\mathrm{P}_{4}$ concentration 
in FF is a possible explanation for the results of Sommer et al. [20], in which inclusion of PGF2 $\alpha$ into gonadotropin stimulation protocol was very effective for the collection of pronuclear stage embryos for biotechnological purposes.

From the present study it seems that hormonal stimulation of estrus increases mRNA expression of both investigated enzymes participating in $\mathrm{P}_{4}$ synthesis (P450scc and $3 \beta H S D)$ in granulosa cells. While in the granulosa cells of PMSG/hCG-treated animals only $3 \beta H S D$ expression was raised, adding $\mathrm{PGF} 2 \alpha$ into the stimulation protocol enhanced the expression of both investigated steroidogenesis-related genes. Similarly to our findings, the studies of Blitek et al. [35] found that induction of estrus with PMSG/hCG + PGF $2 \alpha$ increased the expression of mRNA for steroidogenic pathway genes such as StAR, CYP11A, and $3 \beta H S D$ in the corpus luteum on days 9 and 12 of pregnancy, compared to the animals attaining estrus naturally.

Interestingly, in our study the increase of $3 \beta H S D$ mRNA expression was observed in granulosa cells after stimulation with both PMSG/hCG and PMSG/hCG + PGF2 $\alpha$; however, the increased $\mathrm{P}_{4}$ concentration was found only in animals treated with PMSG/hCG. It may be that the inclusion of PGF $2 \alpha$ in the stimulation protocol increased $\mathrm{P}_{4}$ metabolism, while at the same time not affecting $3 \beta H S D$ mRNA expression stimulated by gonadotropins. A slightly different situation was found in the case of P450scc mRNA, where we did not observe the effect of gonadotropins treatment on its expression; however, its enhanced expression is rather a result of the increased metabolism of $\mathrm{P}_{4}$ induced by PGF2 $\alpha$.

The intra-follicular concentration of $E_{2}$ is considered as a marker for preovulatory maturation, and it increases progressively along with follicle development. In our experiments, both naturally cyclic and hormonally stimulated gilts had a similar $\mathrm{E}_{2}$ concentration in blood serum and FF. However, the results obtained by Wiesak et al. [1] revealed lower levels of $E_{2}$ in the follicles of hormonally treated gilts compared to naturally cyclic animals. In the present study we did not find a relationship between $E_{2}$ concentration and the resumption of meiosis in oocytes. This observation is in agreement with the findings of in vitro experiments [36], where it was suggested that $E_{2}$ is not involved in nuclear maturation of pig oocytes but rather may promote changes in calcium activity during oocyte cytoplasmic maturation [37].

It has been suggested that oocytes of inferior quality are predestined to undergo apoptosis. Changes in the balance between anti- and proapoptotic factors play an important role in the regulation of cellular apoptosis. Our observation that gonadotropins increased the $B C L$ $2 / B A X$ transcript ratio in COCs is in agreement with the antiapoptotic effect on the whole follicles found by Chun et al. [38]. Moreover, it was revealed that PMSG/hCG may suppress apoptotic machinery in rodent granulosa cells $[39,40]$. In our study, a high level of $\mathrm{P}_{4}$ in FF was associated with an increased ratio of BCL-2/BAX mRNA in COCs of PMSG/hCG-stimulated animals. It is possible that this gonadotropin-induced antiapoptotic effect in COCs is mediated through a high $\mathrm{P}_{4}$ content in the FF. In bovine granulosa cells, gonadotropin surges induced the expression of progesterone receptors, promoting their resistance to apoptosis [41]. This relationship was also found in bovine cumulus cells, where treatment with $\mathrm{P}_{4}$ for $24 \mathrm{~h}$ decreased caspase- 3 activity and the ratio of $B A X / B C L 2$ transcripts, while an inhibition of $\mathrm{P}_{4}$ synthesis enzymes increased caspase- 3 activity and the apoptosis in these cells [42]. On the other hand, the ability of oocytes to prevent apoptosis may rely on some maternal specific factors, like BMP15 [43]. The role of BMP15 in apoptosis prevention might be suggested in our study, where high BMP15 transcript levels were found in COCs recovered from hormonally treated animals.

\section{Conclusions}

In conclusion, hormonal induction of estrus with PMSG/ hCG or PMSG/hCG + PGF2 $\alpha$ affected maternal effect gene transcript levels in porcine COCs and oocyte maturation. The high maternal effect genes mRNA content in COCs from hormonally stimulated animals may be caused by some disturbances in maternal transcripts utilization after gonadotropin treatment. The inclusion of PGF2 $\alpha$ into the stimulation protocol seems to be beneficial for maintaining physiological concentration of $\mathrm{P}_{4}$ in FF. Moreover, both hormonal regimens appear to be beneficial for apoptosis prevention through increasing the $B C L$ $2 / B A X$ ratio. Whether the effect of gonadotropins on oocyte maturation and maternal effect gene expression affect also oocyte quality and subsequent embryo development needs to be further studied.

\section{Competing interests}

The authors declare that they do not have competing interests.

\section{Authors' contributions}

MB conceived of the study, participated in its design, coordination and helped to draft the manuscript. MW participated in coordination, collected the tissues and carried out mRNA isolation, GPCR and aceto-orcein staining. AK collected the tissues and carried out Western blot analysis. IB participated in preparation of the manuscript draft and $\mathrm{QPCR}$ analysis. BMJ carried out immunoassays. All authors read and approved the final manuscript.

\section{Acknowledgments}

This research was supported by grant no. NN308573539 from the Ministry of Science and Higher Education, Poland. We sincerely appreciate M. Blitek for help in the care and handling of animals. The correction of English grammar, flow and readability of the manuscript was done by professional service. Anna Kitewska was supported by the European Union within the European Social Fund. 


\section{Author details}

'Institute of Animal Reproduction and Food Research of Polish Academy of Sciences, Tuwima 10, Olsztyn 10-748, Poland. ${ }^{2}$ Department of Animal Physiology, University of Warmia and Mazury, Oczapowskiego 2, Olsztyn 10-719, Poland.

Received: 10 December 2013 Accepted: 27 March 2014

Published: 1 May 2014

\section{References}

1. Więsak T, Hunter MG, Foxcroft GR: Differences in follicular morphology, steroidogenesis and oocyte maturation in naturally cyclic and PMSG/ hCG-treated prepubertal gilts. J Reprod Fertil 1990, 89:633-641.

2. Zięcik AJ, Białłowicz M, Kaczmarek M, Demianowicz W, Rioperez J, Wasielak M, Bogacki M: Influence of estrous synchronization of prepubertal gilts on embryo quality. J Reprod Dev 2005, 51:379-384.

3. Blitek A, Kaczmarek MM, Kiewisz J, Zięcik AJ: Endometrial and conceptus expression of HoxA10, transforming growth factor beta 1, leukemia inhibitory factor, and prostaglandin $\mathrm{H}$ synthase- 2 in early pregnant pigs with gonadotropin-induced estrus. Domest Anim Endocrinol 2010, 38:222-234

4. Martinat-Botté F, Venturi E, Guillouet P, Driancourt MA, Terqui M: Induction and synchronization of ovulations of nulliparous and multiparous sows with an injection of gonadotropin-releasing hormone agonist (receptal). Theriogenology 2010, 73:332-42.

5. Tong Z-B, Gold L, DePol A, Vanevski K, Dorward H, Sena P, Palumbo C, Bondy CA, Nelson NM: Developmental expression and subcellular localization of mouse MATER, an oocyte-specific protein essential for early development. Endocrinology 2004, 145:1427-1434.

6. Pisani LF, Ramelli P, Lazzari B, Braglia S, Ceciliani F, Mariani P: Characterization of maternal antigen that embryos require (MATER/ NLRP5) gene and protein in pig somatic tissues and germ cells. J Reprod Dev 2010, 56:41-48.

7. Uzbekova S, Roy-Sabau M, Dalbiès-Tran R, Perreau C, Papillier P, Mompart F, Thelie A, Pennetier S, Cognie J, Cadoret V, Royere D, Monget P, Mermillod P: Zygote arrest 1 gene in the pig, cattle and human: evidence of different transcripts variants in male and female germ cells. Reprod Biol Endocrinol 2006, 4:12.

8. Tong Z-B, Gold L, Pfeifer KE, Dorward H, Lee E, Bondy CA, Dean J, Nelson NM: Mater, a maternal effect gene required for early embryonic development in mice. Nat Genet 2000, 26:267-268.

9. Zheng P, Dean J: Role of Filia, a maternal effect gene, in maintaining euploidy during cleavage-stage mouse embryogenesis. Proc Natl Acad Sci U S A 2009, 106:7473-7478

10. Sena P, Riccio M, Marzona L, Nicoli A, Marsella T, Marmiroli S, Bertacchini, Fano RA, La Salsa GB, De Pol A: Human MATER localization in specific cell domains of oocyte and follicular cells. Reprod Biomed Online 2009, 2:226-234.

11. Moore RK, Otsuka F, Shimasaki S: Molecular basis of bone morphogenetic protein-15 signaling in granulosa cells. J Biol Chem 2003, 278:304-310.

12. Zhu G, Bingran G, Pan D, Mu Y, Feng S: Expression of bone morphogenetic proteins and receptors in porcine cumulus-oocyte complexes during in vitro maturation. Anim Reprod Sci 2008, 104:275-283.

13. Su YQ, Wu X, O'Brien MJ, Pendola FL, Denegre JN, Matzuk MM, Eppig JJ: Synergistic roles of BMP15 and GDF9 in the development and function of the oocyte-cumulus cell complex in mice: genetic evidence for an oocyte-granulosa cell regulatory loop. Dev Biol 2004, 276:64-73.

14. Kathirvel M, Soundian E, Kumanan V: Differential expression dynamic of growth differentiation factor 9 (GDF9) and bone morphogenetic factor 15 (BMP15) mRNA transcripts during in vitro maturation of buffalo (Bubalus bubalis) cumulus-oocyte complexes. SpringerPlus 2013, 2:206.

15. Wu YT, Tang L, Cai J, Lu XE, Xu J, Zhu XM, Luo Q, Huang H-F: High bone morphogenetic protein-15 level in follicular fluid is associated with high quality oocyte and subsequent embryonic development. Hum Reprod 2007, 22:1526-1531.

16. Gode F, Gulekli B, Dogan E, Korhan P, Dogan S, Bige O, Cimrin D, Atabey N: Influence of follicular fluid GDF9 and BMP15 on embryo quality. Fertil Steril 2011, 95:2274-2278

17. Li HK, Kuo TY, Yang HS, Chen LR, Li SS, Huang HW: Differential gene expression of bone morphogenetic protein 15 and growth differentiation factor 9 during in vitro maturation of porcine oocytes and early embryos. Anim Reprod Sci 2008, 103:312-322.

18. Thelie A, Papillier P, Perreau C, Uzbekova S, Hennequet-Antier C, DalbiesTran R: Regulation of bovine oocyte-specific transcripts during in vitro oocyte maturation and after maternal embryonic transition analyzed using a transcriptome approach. Mol Reprod Dev 2009, 76:773-782.

19. Romar R, De Santis T, Papillier P, Perreau C, Thélie A, Dell'Aquila, Mermillod $P$, Dalbiés-Tran R: Expression of maternal transcripts during bovine oocyte in vitro maturation is affected be donor age. Reprod Domest Anim 2011, 46:23-30.

20. Sommer JR, Collins EB, Estrada JL, Petters RM: Synchronization and superovulation of mature cycling gilts for the collection of pronuclear stage embryos. Anim Reprod Sci 2007, 100:402-410.

21. Kuijk EW, du Puy L, van Tol HT, Haagsman HP, Colenbrander B, Roelen BA: Validation of reference genes for quantitative RT-PCR studies in porcine oocytes and preimplantation embryos. BMC Dev Biol 2007, 7:58-65.

22. Wasielak M, Fujii T, Ohsaki T, Hashizume T, Bogacki M, Sawai K: Transcript abundance and apoptosis in day-7 porcine blastocyst cultured with exogenous insulin-like growth factor-I. Reprod Biol 2013, 13:58-65.

23. Ju S, Rui R, Lu Q, Lin P, Guo H: Analysis of apoptosis and methyltransferase mRNA expression in porcine cloned embryos cultured in vitro. J Assist Reprod Genet 2010, 27:49-59.

24. Walzel H, Brock J, Pöhland R, Vanselow J, Tomek W, Schneider F, Tiemann U: Effects of galectin-1 on regulation of progesterone production in granulosa cells from pig ovaries in vitro. Glycobiology 2004, 14:871-881.

25. Paradis F, Novak S, Murdoch GK, Dyck MK, Dixon WT, Foxcroft GR: Temporal regulation of BMP2, BMP6, BMP15, GDF9, BMPR1A, BMPR1B, BMPR2 and TGFBR1 mRNA expression in the oocyte, granulosa and theca cells of developing preovulatory follicles in the pig. Reproduction 2009, 138:115-129.

26. Bradford MM: A rapid and sensitive method for the quantitation of microgram quantities of protein utilizing the principle of protein-dye binding. Anal Biochem 1976, 72:248-254.

27. Kiewisz J, Kaczmarek MM, Morawska E, Blitek A, Kapelański W, Zięcik AJ: Estrus synchronization affects WNT signaling in the porcine reproductive tract and embryos. Theriogenology 2011, 76:954-966.

28. Guéripel X, Brun V, Gougeon A: Oocyte bone morphogenetic protein 15 , but not growth differentiation factor 9 , is increased during gonadotropin-induced follicular development in the immature mouse and is associated with cumulus oophorus expansion. Biol Reprod 2006, 75:836-843.

29. Isom CS, Li RF, Whitworth KM, Prather RS: Timing of first embryonic cleavage is a positive indicator of the in vitro developmental potential of porcine embryos derived from in vitro fertilization, somatic cell nuclear transfer and parthenogenesis. Mol Reprod Dev 2012, 79:197-207.

30. Shimada M, Terada T: FSH and LH induce progesterone production and progesterone receptor synthesis in cumulus cells: a requirement for meiotic resumption in porcine oocytes. Mol Hum Reprod 2002, 8:612-618.

31. Aparicio IM, Garcia-Herreros M, O'Shea LC, Hensey C, Lonergan P, Fair T: Expression, regulation, and function of progesterone receptors in bovine cumulus oocyte complexes during in vitro maturation. Biol Reprod 2011, 84:910-921.

32. Dode MA, Graves C: Involvement of steroid hormones on in vitro maturation of pig oocytes. Theriogenology 2002, 57:811-821.

33. Silva CC, Knight PG: Effects of androgens, progesterone and their antagonists on the developmental competence of in vitro matured bovine oocytes. J Reprod Fertil 2000, 119:261-269.

34. Abayasekara DR, Michael AE, Webley GE, Flint AP: Mode of action of prostaglandin F2 alpha in human luteinized granulosa cells: role of protein kinase C. Mol Cell Endocrinol 1993, 97:81-91.

35. Blitek A, Morawska-Pucinska E, Szymanska M, Krawczynski K, Ziecik A: Effect of estrus synchronization on luteal P4 synthesis in early pregnant gilts. Reprod Domest Anim 2013, 48(Suppl. 1):72-124.

36. Dode MA, Graves CN: Role of estradiol-17 $\beta$ on nuclear and cytoplasmic maturation of pig oocytes. Anim Reprod Sci 2003, 78:99-110.

37. Wang HF, Isobe N, Kumamoto K, Yamashiro H, Yamashita Y, Terada T: Studies of the role of steroid hormone in the regulation of oocyte maturation in cattle. Reprod Biol Endocrinol 2006, 4:4

38. Chun SY, Billig H, Tilly JL, Furuta I, Tsafriri A, Hsueh AJ: Gonadotropin suppression of apoptosis in cultured preovulatory follicles: mediatory role of endogenous insulin-like growth factor I. Endocrinology 1845-1853, 1994:135. 
39. Xiao CW, Ash K, Tsang BK: Nuclear factor- B-mediated X-linked inhibitor of apoptosis protein expression prevents rat granulosa cells from tumor necrosis factor-induced apoptosis. Endocrinology 2001, 142:557-563.

40. Robles R, Tao XJ, Trbovich AM, Maravel DV, Nahum R, Perez Gl, Nahum R, Perez Gl, Tilly Kl, Tilly JL: Localization, regulation and possible consequences of apoptotic protease-activating factor-1 (Apaf-1) expression in granulosa cells of the mouse ovary. Endocrinology 1999, 140:2641-2644.

41. Quirk SM, Cowan RG, Harman RM: Progesterone receptor and the cell cycle modulate apoptosis in granulosa cells. Endocrinology 2004, 145:5033-5043.

42. Salhab M, Tosca L, Cabau C, Papillier P, Perreau C, Dupont J, Mermillod P, Uzbekova S: Kinetics of gene expression and signaling in bovine cumulus cells throughout IVM in different mediums in relation to oocyte developmental competence, cumulus apoptosis and progesterone secretion. Theriogenology 2011, 75:90-104.

43. Hussein TS, Froiland DA, Amato F, Thompson JG, Gilchrist RB: Oocytes prevent cumulus cell apoptosis by maintaining a morphogenic paracrine gradient of bone morphogenetic proteins. J Cell Sci 2005, 18:5257-5268.

doi:10.1186/1477-7827-12-32

Cite this article as: Bogacki et al:: The effect of hormonal estrus

induction on maternal effect and apoptosis-related genes expression in porcine cumulus-oocyte complexes. Reproductive Biology and

Endocrinology 2014 12:32.

\section{Submit your next manuscript to BioMed Central and take full advantage of:}

- Convenient online submission

- Thorough peer review

- No space constraints or color figure charges

- Immediate publication on acceptance

- Inclusion in PubMed, CAS, Scopus and Google Scholar

- Research which is freely available for redistribution 